\title{
Teenagers' Cultural Values towards Their Vernacular and Indonesian Languages
}

\author{
Anjasmara Tri Dharma, Wan Muthia Lubis, and Nur Alfi Syahra \\ Samudra University, Langsa \\ Email: anjasmara84.am@gmail.com
}

\begin{abstract}
This research is aimed at analysing the teenagers' cultural values towards their vernacular and Indonesian languages. The populations of this research are teenagers around Langsa, especially in old sub district of Langsa named Meurandeh village. They are boys and girls with the age range from 12 to 21 years. The data were collected using questionnaires. The research result shows that teenagers' love and appreciation to their vernacular language have been gradually fading because their parents rarely use the vernacular language and even many have not used it in their home. Only few of them who still consider that it is important to keep their identity. The number of the teenagers who use it as their means of communication with one another in their area is also very low. It is also shown that they do not significantly play a role in preserving the cultures of the region since the preservation is mainly done by the old. It is clear that if the old do not preserve the culture of the region, the culture may gradually vanish. Many of the teenagers tend to use Indonesian language rather than their vernacular language in their daily communication.
\end{abstract}

Keywords: cultural values, vernacular language, mother tounge, regional culture

\section{Introduction}

Language is not only a "property" studied unilaterally by the linguists, but also a means of communication among the human beings. Sturtevant (1942) argues that language is an arbitrary symbol system, a sound used by members of a social group for cooperation and interconnection. In line with Sturtevant's idea, Keraf (1972) states that language is a means of communication between members of the society in the form of symbol of the sounds generated by human vocal organs. These two definitions of languge inform us that language is a very important tool to communicate between human beings in the society. 
Communication is always accompanied by interpretations in which it contains meaning. From a discourse point of view, meaning is never absolute; always determined by various contexts that always refer to the signs contained in human life in which there is culture. Therefore, language is never separated from the cultural context and its existence is always overshadowed by the culture.

Values are the central feature of a culture. They shape tangible cultural differences. The cultural values are the elements or convictions common to a group of people. These determine the way of being and guide the behavior and decisions of individuals within the same group. They are symbols that when united represent the totality of the culture. The cultural values of a group are not always obvious to the naked eye. These are deeply linked to the identity of this group. They constitues the ideas about what is good, right, fair, and just. Besides, they are hereditary and form core of the culture. List of cultural values include customs, rituals conventions, styles and fashions which are remain in the core culture. The values hold supreme position among them. These values give a shape to the culture and the society. These are very difficult to change because they remain in embedded of social institutions and the social norms. These are the ideals of society, and remain in the memory of our elders, in old books, in religious and ethical literature.

Meanwhile, Piaget, a French scholar, in Chaer (2003) mentions that culture (mind) will shape one's language. From here born the theory of cognitive growth by Piaget. Somewhat different from that, Vigotsky, a Russian scholar, holds that language development is earlier one stage before the development of thought (culture) which the two then meet so as to give birth to the fundamental mind and language of thought. Noam Chomsky also agrees that language studies have a close connection with culture. Similarly, Eric Lenneberg has similar views with linguistic theory proposed by Chomsky and Piaget (Chaer, 2003: 52-58). Chaer (2003) also states that the language is unique, and has a very close relationship with the culture of the user, then the analysis of a language is only applicable to that language alone, and cannot be used to analyse other languages. For example, the word "fish" in Indonesian language, it refers to a type of animal that lives in water and is usually eaten as a side dish; in English worth the fish; in Banjar and Javanesse language, it is called iwak. However, the word iwak in Javanesse language means not only "fish" but also "meat" used as a side dish (rice eater). Even, in Javanese language, all side dishes like tofu and tempeh are also called iwak.

Culture, according to Geertz as mentioned by Saifuddin (2006), is a symbol system consisting of symbols and meanings that are shared and which can be identified in public. Geertz (in Saifuddin, 2006) views the cultural context not as a set of general propositions, but as a network of human-knit meanings and in which they operate as if they carry out daily activities. According to him culture consists of socially constructed structures of meaning. It is means that it is a structural system of commonly and publicly identifiable symbols and meanings. The culture of a society is anything that a 
person should know and trust so that he can act in accordance with the norms and values prevailing in society, that knowledge is something to look for and behavior must be learned from others not because of offspring. Culture is therefore a "way" a person must have to carry out daily activities in his life.

According to the Canadian Commission for UNESCO as quoted by Nur Syam said culture is a dynamic value system of learning elements that contain assumptions, agreements, beliefs and rules that allow group members to connect with others and establish communication and building their creative potential. In this concept, culture can be interpreted as a material phenomenon so that the meaning of culture is more observed as a whole system of ideas, actions and human works in the framework of community life. Hence the behavior of humans as members of society will be bound by the culture that looks its form in various institutions that serve as a control mechanism for human behavior.

The teenagers can be said at this time to know less cultural values. In general, teenagers have been influenced by modern societies that they know little their culture. The first influencing factor is their parents. In this research, the parents rarely teach the value of culture-indigo, especially on the local language. Instead parents use Indonesian language more in communication with their children. The regional language is the language of the tribe or culture (thought) that existed in their ancestors. However, the Indonesian language is the language of unity; it is the national language of Republic of Indonesia. People are very rarely unable to use Indonesian language. It is only people in places that are really isolated or still lead primitive lives that cannot use Indonesian language.

Regional languages show that Indonesia has a diversity of cultures as well as in terms of behaviors, customs and languages that each tribe is different. According to Koentjaraningrat as quoted by Chaer (2003), language is part of the culture. Thus, the relationship between language and culture is a subordinate relationship, in which language is under the sphere of culture. Yet another argument is that language and culture have a coordinated relationship, i.e. equal relations, of equal standing. Therefore, language and culture are two systems inherent in humans. If culture is a system that regulates human interaction in society, then linguistics is a system that serves as a means of interaction.

The term "Humanities" comes from the Latin Humanus which can be interpreted as humane, cultured and refined. By studying "Humanities", it is assumed that one 'will be more humane, more cultured and more refined. It can thus be said that "The Humanities" are concerned with the question of values, i.e. human values as homo humans or cultured man. Therefore, humans can become humans, they must learn the science of The Humanities in addition to not leaving other responsibilities as human beings themselves. However, Basic Humanities as a course is not identical with The Humanities. 
Cultural Knowledge (The Humanities) is limited as knowledge that includes the expertise of the branch of science (discipline) art and philosophy. This expertise can be further divided into various other fields of expertise, such as literary arts, dance, music, art and others. As for Basic Humanities as mentioned above, it is an effort that is expected to provide basic knowledge and a general understanding of the concepts developed to examine human and cultural issues. These problems can be approached using the knowledge of culture (The Humanities), whether by a combination of disciplines in cultural knowledge or by using each of the skills in cultural knowledge (The Humanities). In other words, Basic Cultural Sciences use meaningful insights from various fields of cultural knowledge to develop insight into thinking and sensitivity in the study of human and cultural issues.

This research is aiming at revealing the cultural values of teenagers towards their vernacular and Indonesia languages. Besides, it is also to reveal which language of the two which influences the cultural value of teenagers more significantly. By understanding the value of this culture, we will be able to understand the essence of culture and as well as human culture so that it can live and create a new culture.

This research applied Qualitative Research; a process of naturalistic inquiry that seeks in-depth understanding of social phenomena within their natural setting. Creswell (in Herdiansyah, 2010:8), says, "Qualitatative research is an inquiry process of understanding based on distinct methodological traditions or inquiry that explores a social or human problem."

\section{Review of Literature}

Theodorson in Pelly (1994) argues that value is something abstract, which is used as a guide and general principles in acting and behaving. People's or group's attachment to value according to Theodorson is relatively strong and even emotional. Therefore, value can be seen as the purpose of human life itself. According to Koentjaraningrat (1987: 85) another is a cultural value consisting of conceptions of conception that live in the minds of most citizens about things that they consider very noble. The value system that exists within a society is used as an orientation and reference in action. Therefore, a person's cultural values influence him in determining the available alternatives, ways, tools, and production objectives. Clyde Kluckhohn in Pelly (1994) defines cultural values as an organized general conception, which influences behavior related to nature, human positions in nature, people's relationships with people and about desirable and undesirable things that may be related to people's relationships with environment and fellow human beings.

Furthermore, starting from the opinion above, it can be said that every individual in carrying out activities is socially always based on and guided to the values or value systems that exist and live in society itself. This means that values are very much affecting the actions and behavior of humans, either individually, group or society as a whole about good, bad, right or wrong. A value if it has been entrenched within a 
person, then the value will be used as a guide or guidance in behaving. It can be seen in everyday life, such as culture community self-help, culture lazy, and others. Thus, universally, that value is the driving force for a person in achieving a certain goal.

Functionally these value systems encourage individuals to behave as they are determined. They believe that only by behaving that way will they succeed (Kahl, in Pelly, 1994). The value system is an emotionally inherent guideline on a person or a group of people, instead of a life goal to fight for. Therefore, changing the human value system is not easy, it takes time. Therefore, these values are the ideal form of their social environment. It can also be said that the cultural value system of a society is a conceptual representation of their culture, which seems to be beyond and above the individual citizens of that society. There are five basic issues of human life in every culture that can be found universally. According to Kluckhohn in Pelly (1994) the five main issues are: (1) the issue of the essence of life, (2) the nature of work or the work of man, (3) the essence of human status in space and time, (4) the nature of human relationships with the natural environment, and (5) the essence of human relationships with human beings. Various cultures conceptualize this universal problem with many different variations.

\section{Methodology}

\section{Research Design}

Teenager is a teenage man's time. In adolescence, man cannot be called adult but cannot also be called children. Adolescence is a period of human transition from children to adulthood. Adolescents are a transitional period between childhood and adulthood that runs between the ages of 12 years to 21 years.

Teenager language is also regarded as a variant of local languages and Indonesian language that socially indicates that social groups that use the language are teenagers. In many contexts, the use of adolescent language today shows different forms. The use of local and Indonesian languages currently used by adolescents leads to adolescent cultural values. This article aims to describe the cultural value of adolescents to local and Indonesian languages that will conduct direct interviews with adolescents. The data of this study is to see the comparison of the cultural values of adolescents to local and Indonesian languages in the form of tribes, customs that exist in adolescents. The method used in this research is qualitative method. Data collection is done by using referral method with question technique.

\section{Subject of Research}

Respondents in this research are teenagers around Langsa, especially in old Langsa sub district named Meurandeh village. The teenagers consist of boys and girls with the age from 12 to 21 years old. 


\section{Instrument of Research}

In this research, the researcher used questionnaire in order the answer and get the data systemically based on the research problems. Questionnaire refers to a set of questions that is written in the places of paper in order to get some information.

According to Subana and Rahadi (2000), there are two types of questionnaire, those are structure or close form questionnaire and unstructured or open form questionnaire. A structure or close form questionnaire contains of the questions and alternatives answer to them. The answers provided for each questionnaire should be exhaustive answers of all possible responses at the same time mutually exclusive, a structured close form include suggested answer. So the respondents should choose the chosen answer. The administration and scoring of a structured questionnaire are straight forward and the result lends them to analyze. An unstructured or open form does not include suggested answers.

The respondents will be given subjective question, in which the respondents are given an opportunity to answer the question freely, based on their opinion. In addition, according to Singarimbun and Effendi (1995), there are three kinds of questionnaire, those are: close-form question, open form question, and semi open form question. Close form question is the respondent has no chance to answer the question freely, because in this form has been there the answer. For example: 'yes' and 'no' question. Open form question is the respondent can answer the question based on their opinion, because in open question there is no alternatives answer for the respondents. The last is semi open question, in this question there is an alternatives answer but the respondent can also give the answer based on their opinion. This research takes the combination of both questionnaire types (close form, Open form, and semi open question) above because in addition to the value able choice. The respondents were also given the change to answer and solve the question based on the personal opinion. Data collection is one of the most important research techniques. To obtain valid data, researchers will use this type of data collection. In collecting the data, the researchers used several data collection techniques, namely: observation, non-participant observation and questionnaires. Organizing the instrument is an important activity in the research but data collection is more important, especially when the researcher uses a strong method of entry of the subjective elements of the researcher. That is the importance of collecting data in research, it must be taken seriously so that the results obtained in accordance with the function of the appropriate data collection and correct. 


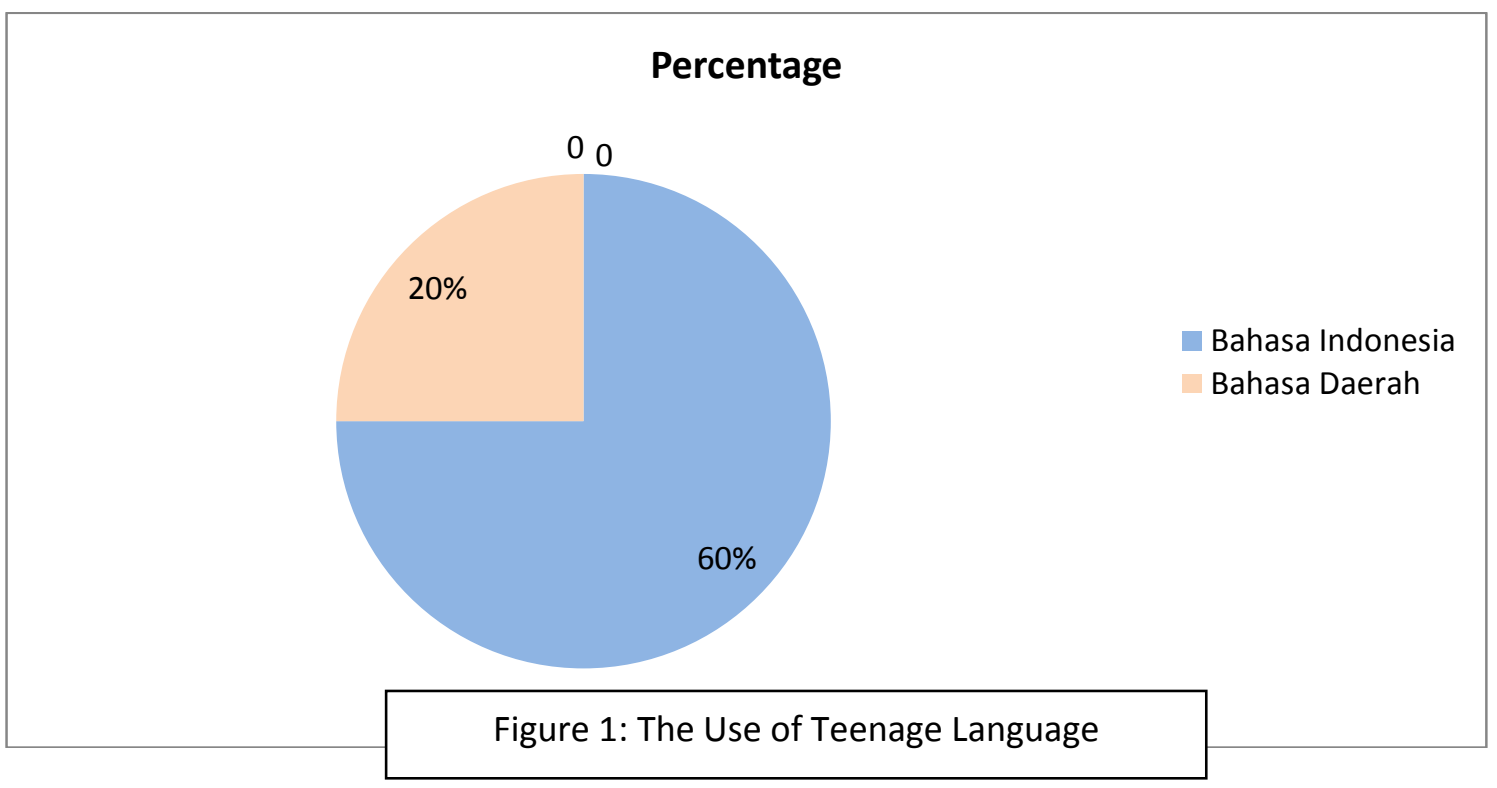

\section{Discussion}

This research has been surveyed by respondents in questions. Comparison of cultural values of adolescents to local and Indonesian languages are identified in this research. The research indicates that many benefits can be developed in the community. In this case, this research explains that the cultural values of adolescents are very influential on their regional and Indonesian languages. Each respondent has a different perspective; therefore, this research can be a solution to the community in order to maintain the culture. From the respondents' answers to the questions that have been given, it is found that each respondent has a different ideology to the local and Indonesian languages.

First, the cultural values of adolescents towards the local language has been proven in this case. Each adolescent has a view of cultural values on the tribe owned. Their point of view has been spotted in the communication they use every day using language. Teenagers have now followed the modern era in which cultural values have gradually faded. The number of teenagers who still apply cultural values is very little. On the other hand, adolescents are not taught or guided by their parents to always instill in them the cultural values. The result of this study shows that the teenagers do not have significant role to maintain the cultural values and to remain in the channel to their offspring. It usually happens to the teenagers who have different cultural values from the regional languages. A tribe does not become an important view for the cultural values of the teenagers. Besides, there are only few teenagers who use their regional language, instead they prefer using Indonesian language.

Second, on the cultural values of the teenagers towards Indonesian language, many teenagers use Indonesian language because it commonly becomes their first language, and it is also the national language or the language of the country. It is not only in the area that uses the local language but also in all the regions in Indonesia, teenagers 
have been using Indonesian language as their means of communicion in daily life. Cultural values towards Indonesian language have been taught in schools. In Indonesia, Indonesian language becomes the language of teaching process or transfering knowledge. There are only few schools which use local languages or vernacular languages in the formal teaching learning process. It may happen only in the schools in which their students have the same cultural values. Meaning that all the students can understand the local language used. This is the vivid reason why Indonesian language can be the first language as well as the the second language for the teenagers. It usually depends on the place and environmental conditions of the teenagers.

Parents are the main agents in bridging children towards ethnic, cultural, and local languages. But most parents today are no longer using local languages as the primary language when communicating with their family members at home. Parents tend to use Indonesian language when talking to their children so that their role which is actually very vital in transmitting the cultural values of the region, especially disseminating regional languages as a means of daily communication becomes weak and loose it liveliness. Lack of socialization of parents resulted in children to no longer make the local language as a sense of belonging. Even some of the children have not recognized and understood their local language at all.

The younger generation prefers to preserve the language of slang and foreign language rather than its own local language. The culture and values prevailing in today's youth have disregarded regional languages. They are "hypnotized" for the sheer luxury of the slang language that develops in everyday life. No longer is there awareness that regional languages are a sublime cultural heritage that must be preserved. They again realized that they had "killed" their own cultural treasures.

The advancement of sophisticated and modern civilization has created the process of globalization and has made the world like a giant village/village that is connected by the communication media that continue undergoing developments. The ease of access to communication and information perceived as an implication of such progress is nothing more than a parasite that undermines the fertility of regional languages. The media is nothing more than a foreign "cultural broker", including foreign languages, that internalize foreign languages to the public so that they will be conserved in the language of their region, the language of their nation.

\section{Conclusion}

From the data achieved from the respondents, it is seen that teenagers tend to use Indonesian language rather than their vernacular language. Many of them do not really love and appreciate their vernacular language anymore. Only few of them realize that the vernacular language is very important to keep their identity so that they rarely use their vernacular language as a means of communication with their friends in their environment. Many teenagers cannot communicate with the vernacular language so 
that they use Indonesian language which is the national language as well as the language of unity.

Few teenagers still have an ideology towards the values of their culture because their parents do not teach them the vernacular language and the cultural values. So teenagers can find out positive things from their vernacular language positions. Teenagers use the vernacular language only to the persons who come from the same tribe as theirs and to the parents. However, many parents have not used the vernacular language as a means of communication with their family members including with their children at home so that many teenagers cannot communicate with the vernacular language.

However, many teenagers still realize that cultural values in the existing area are still very important to be respected, such as Acehnese culture, Javanesse culture, Bataknesse Culture, and Padangnesse culture in Langsa. The teenagers' perspective on the cultural values shows that their understanding on the cultural values is lacking.

Teenagers in Meurandeh Langsa do not significantly play active role in preserving the culture of the region because they regard that it is their parents who ought to preservve it. Theerefore, it is quite clear that if parents do not also preserve the culture of the region, then certainly the culture will gradually vanish.

\section{References}

Atmowiloto, Arswendo. (1982). Komik Dan Kebudayaan Nasional, Jurnal Analisis Kebudayaan.

C. Ewig, Michael. (2014). Language Endangerment in Indonesia. The University of Melbourne. Vol. 8 No. 1 (1 December 2014)

Hadi, Sutrisno. (2004). Metodology Research. Jilid 4. Penerbit Andi. Yogyakarta

Keraf, Gorys. (1997). Komposisi: Sebuah Pengantar Kemahiraan Bahasa. Ende. Flores: Penerbit Nusa Indah.

Moleong, Lexy J. (2000). Metodologi Penelitian Kualitatif. Remajaroskarya. Bandung

Monto Bauto, Laode (2013). Socio Cultural Values as Community Local Wisdom Katoba Muna in The Development of Learning Materials Social Studies and History. Vol. XIV, No.2 (1 December 2013).

Pelly, Usman. (1994). Urbanisasi dan Adaptasi: Peranan Misi Budaya Minangkabau dan Mandailing. Jakarta: LP3ES.

Shinta Sukowati Suwarto, Ratna. (2014). Nilai Budaya dalam Dongeng-Dongeng di Kabupaten Cianjur untuk Pengembangan Pendidikan Karakter. Vol. 5, No. 1 (1 April 2014).

Singarimbun, Masri and Efendi, Sofia. (1995) Metode Penelitian Survey. Jakarta: LP3ES.

Sujarwa. (2011). Ilmu Sosial dan Budaya Dasar: Manusia dan Fenomena Sosial Budaya. Yogyakarta: Pustaka Belajar

Rahadi, Moursetyo and Subana. (2000). Statistic Pendidikan. Bandung: Pustaka Setia. 
Saifuddin, Achmad Fedyani. (2006). Antropologi Kontemporer; Suatu Pengantar Kritis mengenai Paradigma. Jakarta: Kencana.

Samsuri. (1978). Analisa Bahasa. Jakarta: Erlangga.

Sturtevant, Edgar H. (1942). Linguistic Change: An Introduction to the Historical Study of Language. New York: Stechert.

Trudgill, P. (1987). Sociolinguistics: An Introduction to Language and Society. Victoria: Penguin Book, Ltd.

Yule, G. (1990). The Study of Language. Cambridge University Press.

Yuianti, Ling. (2013). Cultural Values Inheritance of Cikondang Indigenious People in History Learningin Madrasah Aliyah Al- Hijrah. Vol. XIV, No 2 (1 December 2013).

Wardhaugh, R. (1992). An Introduction to Sociolinguistics (Second Edition). Oxford: Blackwell Publishers.

Zamzani. (2013). Muatan Kompetensi Berbahasa Indonesia Dalam Kurukulum 2013. Yogyakarta: PBSI FBS UNY. 